\title{
COMPARISON OF THE NIST AND EUROPEAN GOLD COATING STANDARDS
}

\section{R. Beauchamp \\ H. G. Brown \\ D. S. Lashmore}

U.S. DEPARTMENT OF COMMERCE Natlonal Instltute of Standards and Technology

Galthersburg, MD 20899
U.S. DEPARTMENT OF COMMERCE Robert A. Mosbacher, Secretary Lee Mercer, Deputy Under Secretary for Technolosy

NATIONAL INSTITUTE OF STANDARDS AND TECHNOLOGY

Raymond G. Kammer, Acting Director 



\section{COMPARISON OF THE NIST AND EUROPEAN GOLD COATING STANDARDS}

\section{R. Beauchamp \\ H. G. Brown \\ D. S. Lashmore}

U.S. DEPARTMENT OF COMMERCE Natlonal Instltute of Standards and Technology

Galthersburg, MD 20899

January 1990

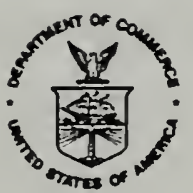

U.S. DEPARTMENT OF COMMERCE Robert A. Mosbacher, Secretary Loe Mercer, Deputy Under Secretary for Tochnology

NATIONAL INSTITUTE OF STANDARDS AND TECHNOLOQY

Raymond G. Kammer, Acting Director 



\title{
COMPARISON OF THE NIST AND EUROPEAN GOLD COATING STANDARDS
}

\author{
b y \\ C. R. Beauchamp, H. G. Brown, and D. S. Lashmore \\ National Institute of Standards and Technology \\ Gaithersburg, Maryland
}

\section{Introduction}

The goal of the present study is to compare the gold coating standards produced by the National Institute of Standards and Technology (NIST) with the ones produced by the Community Bureau of Reference (BCR) of the Commission of the European Communities. The nominal mass per unit area for the standards produced at NIST are $1.5,3,6,14 \mathrm{mg} / \mathrm{cm}^{2}$ and the BCR standards are $1,1.5,6,10$ $\mathrm{mg} / \mathrm{cm}^{2}$. This comparison is in response to questions raised by BCR regarding the accuracy of NIST standards, especially in the range of $14 \mathrm{mg} / \mathrm{cm}^{2}$.

\section{Methods used for the comparison}

Three different measurements techniques were used in this study to comply with the self- imposed criteria of cross referencing measurements with two different techniques. Wavelength dispersive fluorescent $\mathrm{x}$-ray techniques were employed for the majority of the standards using a Norelco NB18-A (Norelco) with an aperture diameter of $1 \mathrm{~cm}$. The exceptions were the 10 and $14 \mathrm{mg} / \mathrm{cm}^{2}$ samples which were measured by B-backscatter techniques using a Fischerscope Beta 850 (Fischerscope) with an aperture diameter of $1.6 \mathrm{~mm}$. For the cross-referencing of the measurements energy dispersive fluorescent $\mathrm{x}$-ray techniques were employed for all the samples using a Seiko SFT7450 (Seiko) with an aperture diameter of $0.3 \mathrm{~mm}$. For the nominal mass per unit area, the laboratory that manufactures the standard, and the corresponding measurement technique employed refer to Table 1. 


\begin{tabular}{|c|c|c|c|c|c|}
\hline \multirow{2}{*}{$\mathbf{m g} / \mathbf{c m}^{2}$} & \multirow{2}{*}{ NIST } & \multirow{2}{*}{ BCR } & B-Backscatter & \multicolumn{2}{|c|}{ X-Ray Fluorescence } \\
\cline { 4 - 6 } & & & Fischerscope & Norelco & Seiko \\
\hline 1 & & $\bullet$ & & $\bullet$ & $\bullet$ \\
\hline 1.5 & $\bullet$ & $\bullet$ & & $\bullet$ & $\bullet$ \\
\hline 3 & $\bullet$ & & & $\bullet$ & $\bullet$ \\
\hline 6 & $\bullet$ & $\bullet$ & & $\bullet$ & $\bullet$ \\
\hline 10 & & $\bullet$ & $\bullet$ & & $\bullet$ \\
\hline 14 & $\bullet$ & & $\bullet$ & & $\bullet$ \\
\hline
\end{tabular}

Table 1. Techniques used for comparing the gold standards.

Three major difficulties were encountered during the study. They follow with the respective corrective action taken to overcome them. (1) NIST does not usually certify samples below the $1.5 \mathrm{mg} / \mathrm{cm}^{2}$, so the lowest masters $( \pm 1 \%)$ available at NIST are $1.24 \mathrm{mg} / \mathrm{cm}^{2}$. Thus, a different calibration procedure was required for the $1 \mathrm{mg} / \mathrm{cm}^{2}$ samples. For the measurement of samples using the Seiko and the Norelco a calibration curve was constructed using the masters for the $1.5 \mathrm{mg} / \mathrm{cm}^{2}$ standards and previously certified samples $( \pm 5 \%)$ in the neighborhood of $0.60 \mathrm{mg} / \mathrm{cm}^{2}$ to bracket the high and low ends, respectively. This method complied with the proprietary criteria built in the Seiko instrument for a satisfactory calibration curve and was consistent with the NIST criteria of less than $1 \%$ deviation between analyzed and calculated values. (2) A similar problem with masters for the $10 \mathrm{mg} / \mathrm{cm}^{2}$ was encountered. In this case masters bracketing the range of interest between 6 and $14 \mathrm{mg} / \mathrm{cm}^{2}$ exist, but they are farther apart making it difficult to select a set of masters that met the calibration criteria. As was to be expected, the higher masters for the $6 \mathrm{mg} / \mathrm{cm}^{2}$ and the lower masters for the $14 \mathrm{mg} / \mathrm{cm}^{2}$ were satisfactory, but careful selection was still required. The range finally used was from 6.92 to $11.90 \mathrm{mg} / \mathrm{cm}^{2}$. (3) The longer exposure time for the heavier samples caused unwanted drift during the measurement when using the Norelco. To overcome this problem the $B$-backscatter technique was employed.

\section{Density per Unit Area Measurements:}

Typical calibration curves used for the Norelco are presented in Figure 1, followed by the corresponding equations for each range in Table 2. In addition, the masters used for each region are listed by the 
corresponding equation. For the Seiko and the Fischerscope the internal calibration procedure was followed and their proprietary calibration algorithm was employed.

Acceptable and reproducible values were obtained for all the samples measured, including crossreferenced measurements of the samples with the different instruments. A comparison of the area density, $\mathrm{t}\left(\mathrm{mg} / \mathrm{cm}^{2}\right)$, of NIST's and BCR's standards as measured by different instruments is presented in Figures 2 and 3 respectively. Table 3 represents the percent deviation from the certified value for the standards produced at NIST, and Table 4 the deviation with respect to the average value measured for the standards

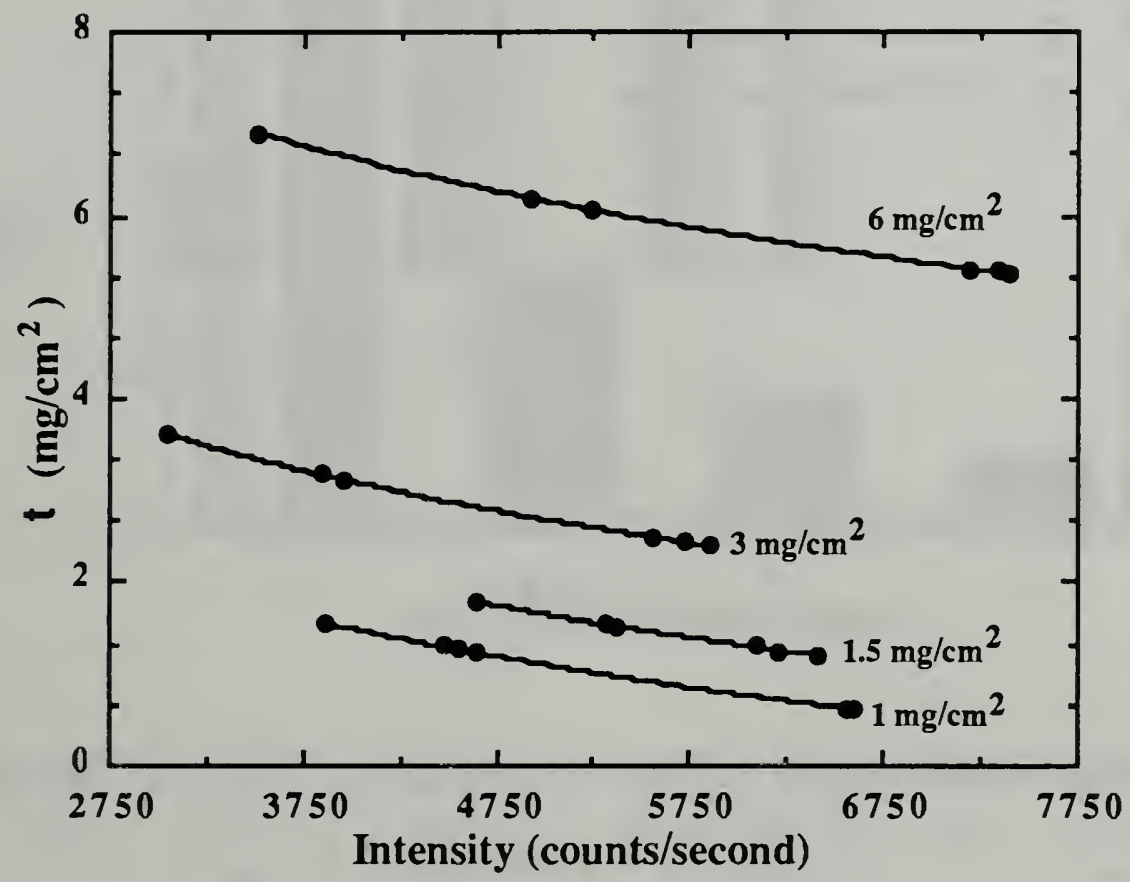

Figure 1. Typical calibration curves for the Norelco NB18-A.

\begin{tabular}{|l|l|l|l|l|}
\hline \multirow{2}{*}{$\mathrm{mg} / \mathrm{cm}^{2}$} & \multicolumn{3}{|c|}{$\begin{array}{c}\text { Equation } \\
\left(\mathrm{mg} / \mathrm{cm}^{2}\right)=\mathrm{A}-\mathrm{B}^{*} \operatorname{In}(\mathrm{C})\end{array}$} & \multirow{2}{*}{ Masters } \\
\cline { 2 - 4 } & $\mathrm{A}\left(\mathrm{mg} / \mathrm{cm}^{2}\right)$ & $\mathrm{B}\left(\mathrm{mg} / \mathrm{cm}^{2}\right)$ & $\mathrm{C}$ (adimensional) & \\
\hline 1 & 16.054 & 1.75481 & Intensity ${ }^{\dagger}-1$ & $.62 \ddagger, .63 \ddagger, 1.25,1.27,1.31,1.55$ \\
1.5 & 14.592 & 1.54823 & Intensity -753 & $1.22,1.26 .1 .31,1.53,1.55,1.79$ \\
3 & 16.4866 & 1.63946 & Intensity -465 & $2.40,2.44,2.50,3.11,3.17,3.61$ \\
6 & 22.0561 & 1.88590 & Intensity -405 & $5.36,5.39,5.41,6.06,6.19,6.89$ \\
\hline
\end{tabular}

$\dagger$ counts/second $\ddagger$ certified standards

Table 2. Calibration equations corresponding to curves on Figure 1. 
produced at $\mathrm{BCR}$. It is recognized that comparison with the average value of the European standards is somewhat arbitrary. It should not imply that these averages represent the BCR certified values. A comparison with BCR's certified values is not presented since a certified set was not provided.

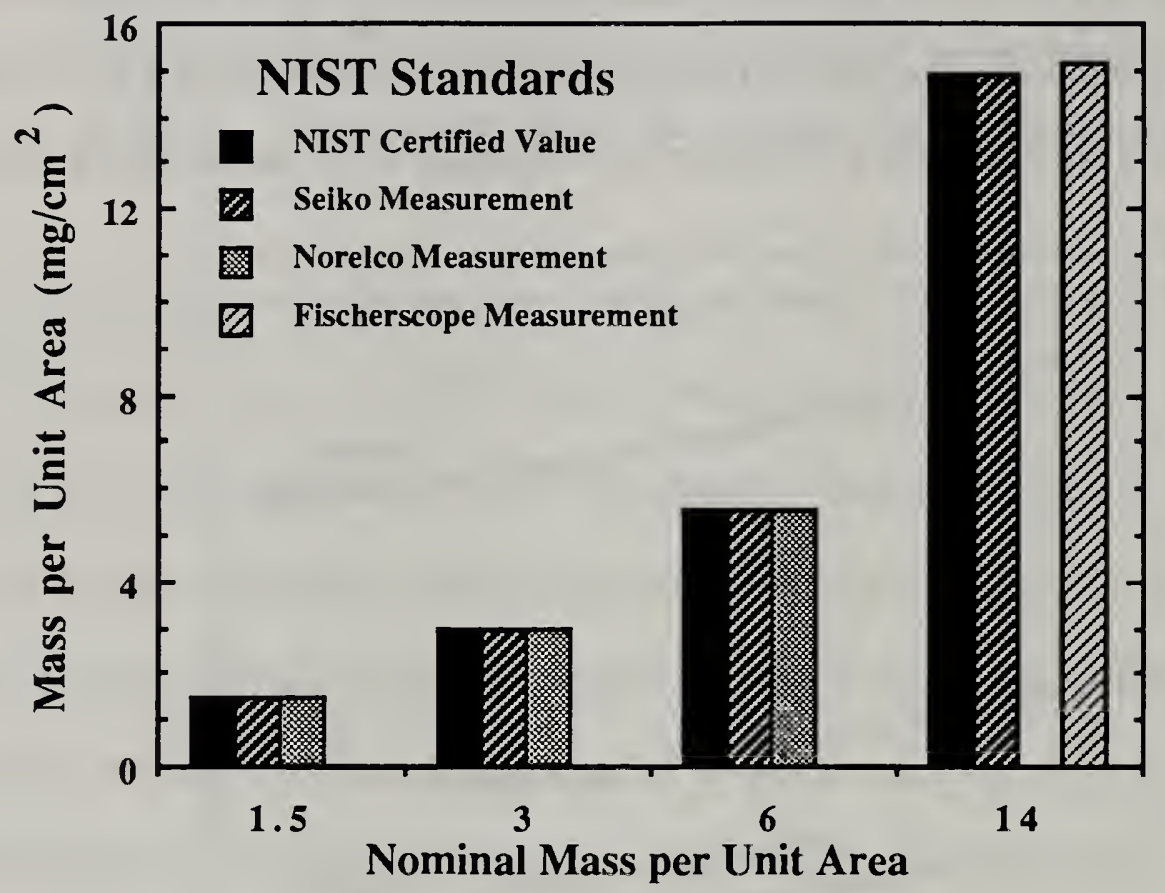

Figure 2. Comparison between different measuring techniques for various NIST certified standards.

\begin{tabular}{|c|c|c|c|c|c|c|c|}
\hline $\begin{array}{c}\text { nominal } \\
\mathrm{mg} / \mathrm{cm}^{2}\end{array}$ & $\begin{array}{c}\text { NIST } \\
\text { Certified } \\
\text { Value }\end{array}$ & $\begin{array}{c}\text { Norelco } \\
\text { Measure- } \\
\text { ment }\end{array}$ & $\begin{array}{c}\% \\
\text { Diff. }\end{array}$ & $\begin{array}{c}\text { Seiko } \\
\text { Measure- } \\
\text { ment }\end{array}$ & $\begin{array}{c}\% \\
\text { Diff. }\end{array}$ & $\begin{array}{c}\text { Fischerscope } \\
\text { Measure- } \\
\text { ment }\end{array}$ & $\begin{array}{c}\% \\
\text { Diff. }\end{array}$ \\
\hline 1.5 & 1.51 & 1.51 & 0.0 & 1.50 & 0.7 & - & - \\
3 & 2.95 & 2.94 & 0.3 & 2.99 & 1.4 & - & - \\
6 & 5.55 & 5.55 & 0.0 & 5.53 & 0.4 & - & -15.05 \\
\hline
\end{tabular}

Table 3. Percent deviation of the measurement from the certified values for NIST's standards. 


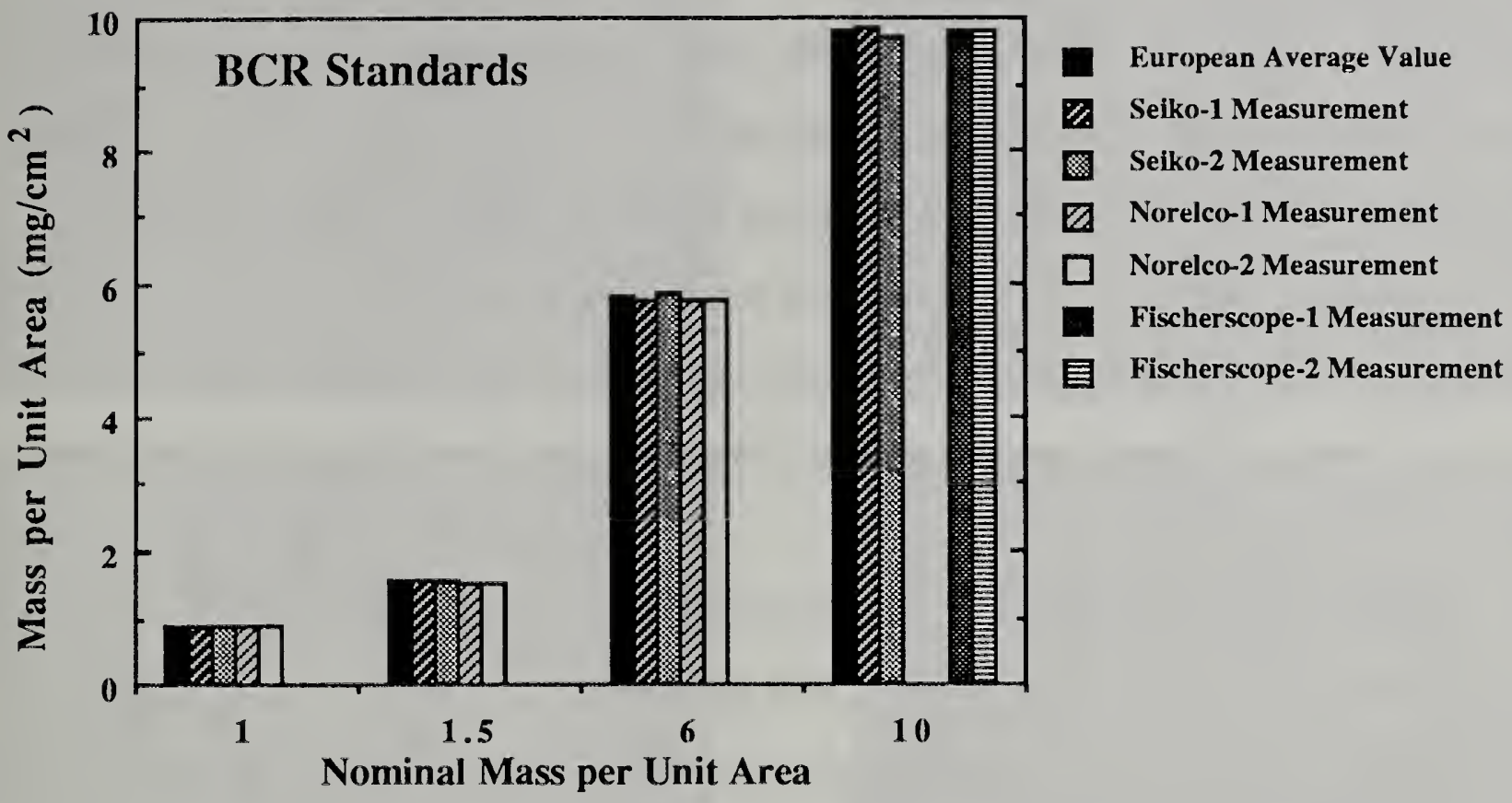

Figure 3. Comparison between different measuring techniques for two sets of BCR standards.

\begin{tabular}{|c|c|c|c|c|c|c|c|c|}
\hline $\begin{array}{c}\text { nominal } \\
\mathrm{mg} / \mathrm{cm}^{2}\end{array}$ & $\begin{array}{c}\text { Intended } \\
\text { Value } \dagger\end{array}$ & $\begin{array}{c}\text { BCR } \\
\text { Measured } \\
\text { Average } \ddagger\end{array}$ & $\begin{array}{c}\text { Norelco } \\
\text { Measure- } \\
\text { ment }\end{array}$ & $\begin{array}{c}\% \\
\text { Diff. }\end{array}$ & $\begin{array}{c}\text { Seiko } \\
\text { Measure- } \\
\text { ment }\end{array}$ & $\begin{array}{c}\% \\
\text { Diff. }\end{array}$ & $\begin{array}{c}\text { Fischerscope } \\
\text { Measure- } \\
\text { ment }\end{array}$ & $\begin{array}{c}\% \\
\text { Diff. }\end{array}$ \\
\hline 1.0 & 0.863 & 0.87 & 0.86 & 1.1 & 0.87 & 0.0 & - & $Z$ \\
1.5 & 1.570 & 1.54 & 0.87 & 0.0 & 0.87 & 0.0 & - & - \\
6 & 5.823 & 5.79 & 1.52 & 1.3 & 1.56 & 1.3 & - & - \\
10 & 9.597 & 9.79 & 5.76 & 0.5 & 1.54 & 0.0 & - & - \\
\hline
\end{tabular}

$\dagger$ As reported on "Certification report for gold thin film BCR CRM 328"

$¥$ Average of all measurements performed on the European Standards

Table 4. Percent deviation of the measurement from the average values for BCR's standards. Based on the "intended value" column it is demonstrated that NIST masters can reproduce the measurements; however, comparison with certified values was not possible since they were not available. 


\section{Surface Analysis:}

A study using the Seiko was carried out to show the importance of surface smoothness on thickness determination. Using a rough infinitely thick sample, a calibration curve was created, and the procedure was repeated after polishing the same sample. Based on those curves a certified $14.90 \mathrm{mg} / \mathrm{cm}^{2}$ sample was measured as 14.73 and $14.90 \mathrm{mg} / \mathrm{cm}^{2}$ with the first and second calibration curves respectively. Comparison with the sputtered BCR's infinitely thick sample was not possible since such sample was not made available. This analysis suggests that roughness may affect the calibration curve for thicker samples, and perhaps for the thinner ones as well when using curve fitting algorithms that require an infinitely thick standard.

A scanning electron microscopy (SEM) analysis of the surface of the standards revealed a clear difference between the sputtering process used at BCR and the electrodeposition technology employed at NIST. The SEM pictures presented in Figure 4 (a, b, c, and d) for NIST's standards and 5 (a, b, c, and d) for BCR's standards demonstrate that the thicker a sputtered sample is, the rougher the surface becomes with pits increasing in size as the coating becomes thicker. Although an average mass per unit area is reported by the measuring devices, uniform surface texture probably plays a role in determining the reported value and the pit density may be important as well. The morphology may be important when using one type of standard to certify a sample produced using a different deposition technique.

\section{Summarv:}

(1) Reproduction of our certified thicknesses has been accomplished well within NIST claimed deviation of $5 \%$ and in reality the NIST standards studied here are within $1.0 \%$ maximum deviation of the certified values on all samples when using the Norelco and Fischerscope instruments (which is the standard procedure) and within $1.4 \%$ when using the Seiko.

(2) The surfaces of both NIST's and BCR's standards, are scratched due to the excessive handling before shipping. Gold thickness standards produced at NIST are measured with the Norelco and there is almost no way to measure them without some scratching of the samples since they are placed upside-down in an aluminum chamber. For future production of the gold thickness standards, a new method is 


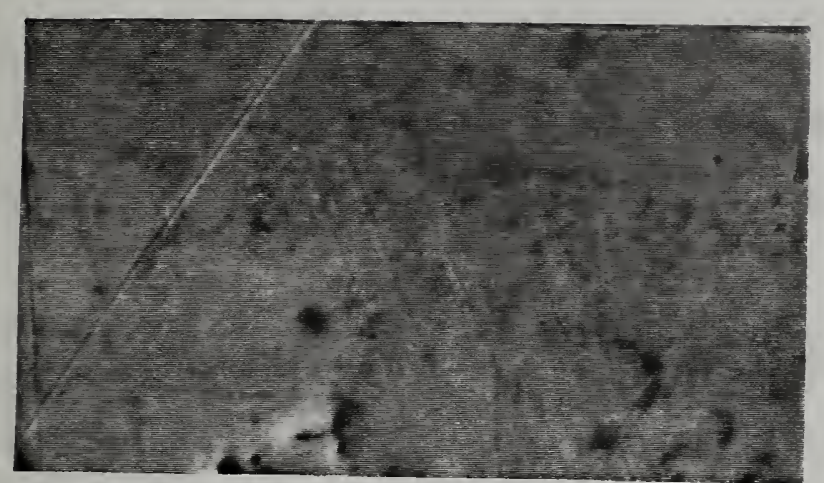

(a)

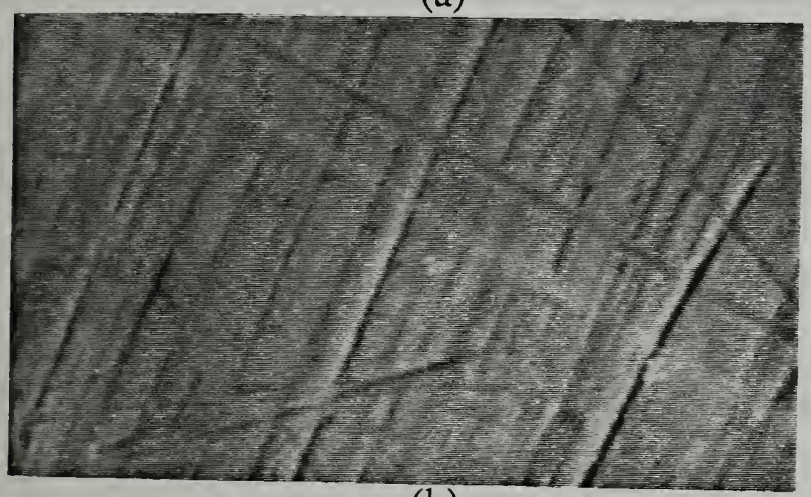

(b)

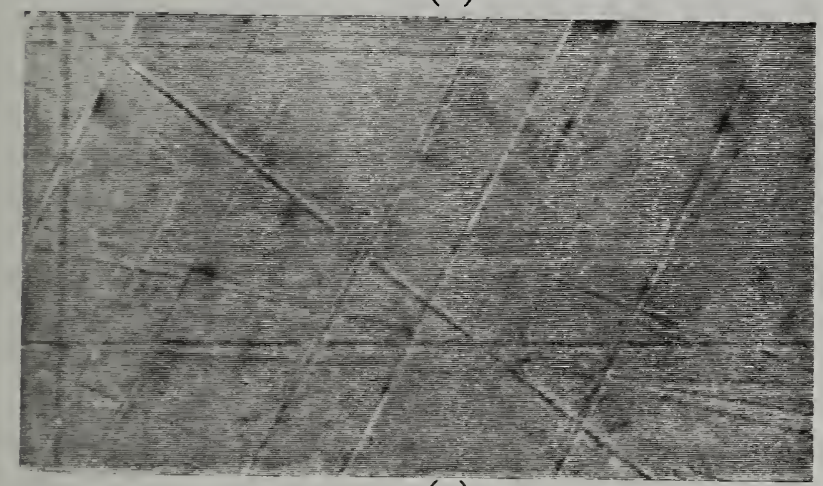

(c)

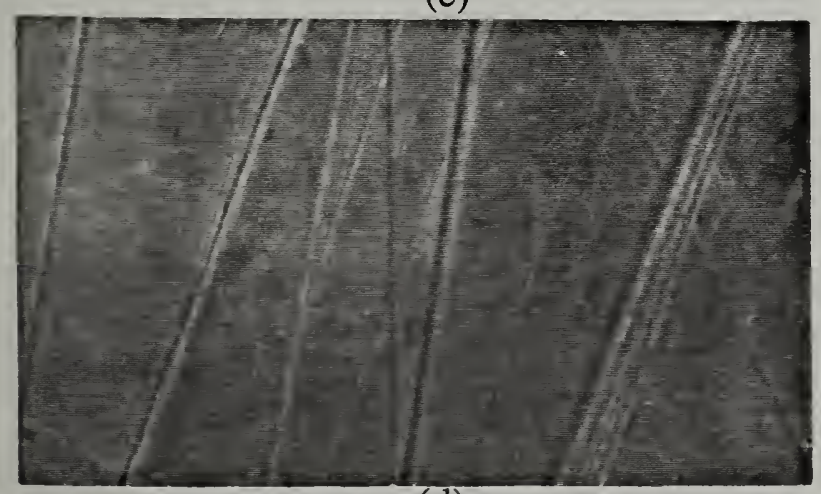

(d)

Figure 4. SEM micrographs of NIST's standards (a) 1.5, (b) 3.0 , (c) 6.0, and (d) 14.0 nominal $\mathrm{mg} / \mathrm{cm}^{2}$.

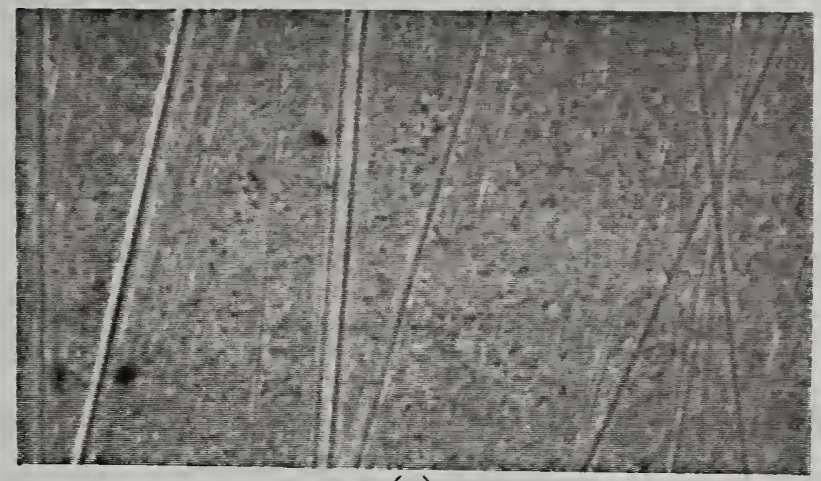

(a)

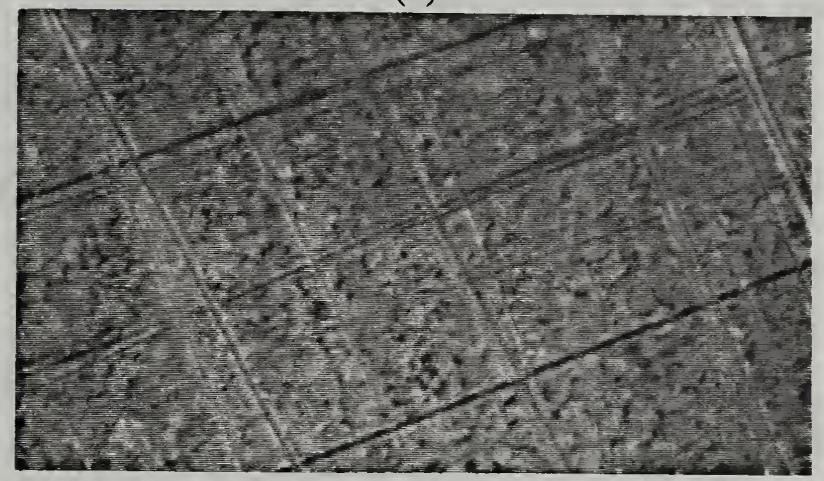

(b)

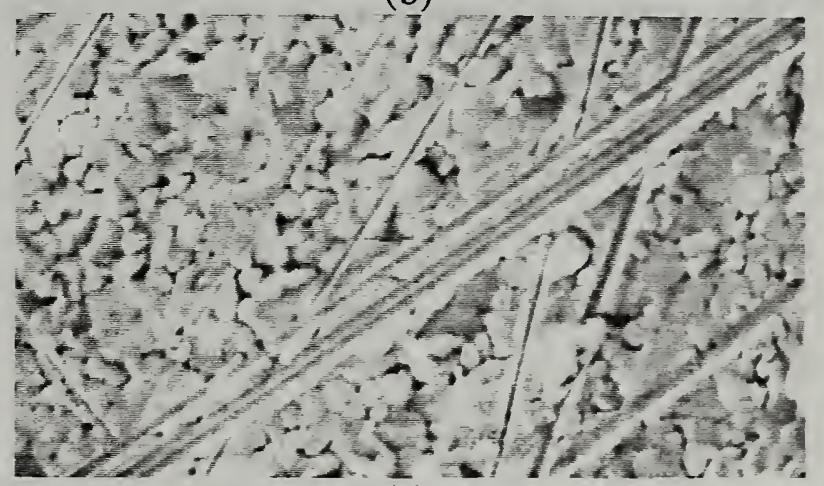

(c)

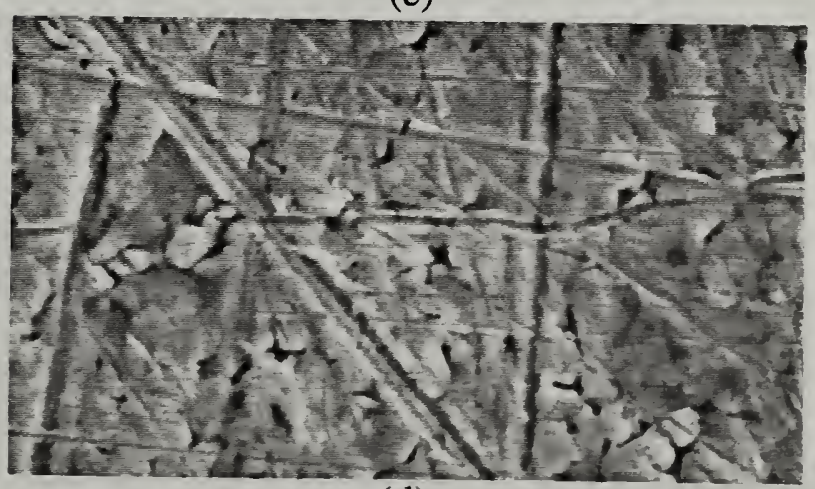

(d)

Figure 5. SEM micrographs of BCR's standards (a) 1.0, (b) 1.5, (c) 6.0, and (d) 10.0 nominal $\mathrm{mg} / \mathrm{cm}^{2}$. 
being developed to minimize handling during preparation and packaging.

(3) Sputtered BCR samples become rough and develop large pits as they become thicker.

(4) It appears that difficulties arise when using energy dispersive instruments incorporating a requirement for the measurement of an infinitely thick standard. Calibration curves that require said measurement depends on surface roughness.

(5) The deviations for the BCR samples were reproduced within $1.3 \%$ when using NIST Standards. This should not be interpreted as meaning the BCR standards are this accurate since actual certified values were not provided by $\mathrm{BCR}$ for the comparison.

(6) Deviations of the measurements are generally larger when using the Seiko system (energy dispersive). All NIST standards are certified using the Norelco system (wavelength dispersive - larger aperture).

\section{Acknowledgements:}

The authors are grateful to Dr. Nea Wheeler for her help in the preparation of the SEM micrographs. 


\section{BIBLIOGRAPHIC DATA SHEET}

\section{TITLE AND SUBTITLE}

Comparison Study Between the NIST and European gold Standards

\section{AUTHOR(S)}

C. R. Beauchamp, H.G. Brown, D.S. Lashmore

\section{PERFORMING ORGANIZATION (IF JOINT OR OTHER THAM NIST, SEE INSTRUCTIONS) U.S. DEPARTMENT OF COMMERCE NATIONAL INSTITUTE OF STANDARDS AND TECHNOLOGY GATHERSBURG, MD 20899}

7. CONTRACT/GRANT NUMBER

8. TYPE OF REPORT AND PERIOD COVERED

\section{SPONSORIMG ORQANIZATION NAME AND COMPLETE ADDRESS (STREET, CITY, STATE, ZIP)}

DOCUMENT DESCRIBES A COMPUTER PROGRAM; SF-185, FIPS SOFTWARE SUMMARY, IS ATTACHED. 1. ABSTRACT (A 2OO-WORD OR LESS FACTUAL SUMMARY OF MOST SIGNIFICANT INFORMATION. IF DOCUMENT INCLUDES A SIGNIFICANT BIBLOGRAPHY OR UTERATURE SURVEY, MENTION IT HERE.)

Gold coating standards produced by the National Institute of Standards and Technology (NIST) are compared with those produced by the Community Bureau of Reference (BCR) of the Commission of the European Communities. The nominal mass per unit area for the standards produced at NIST are $1.5,3,6,14 \mathrm{mg} / \mathrm{cm}^{2}$ and the BCR standards are $1,1.5,6,10 \mathrm{mg} / \mathrm{cm}^{2}$. This comparison is in response to questions raised by BCR regarding the accuracy of NIST standards, especially in the range of $14 \mathrm{mg} / \mathrm{cm}^{2}$. The reproduction of NIST certified thicknesses has been accomplished well within claimed deviation of $5 \%$. The surfaces of both NIST's and BCR's standards, are scratched due to extensive handling. Sputtered BCR samples become rough and develop large pits as they become thicker. It appears that difficulties arise when using energy dispersive instruments incorporating a requirement for the measurement of an infinitely thick standard. The deviations for the BCR samples were reproduced within $1.3 \%$ when using NIST standards. This should not be interpreted as meaning the BCR standards are this accurate since actual certified values were not provided for the comparison. Deviations of the measurements are generally larger when using energy dispersive measuring techniques. All NIST standards are certified using wavelength dispersive measuring techniques.

\section{KEY WORDS (6 TO 12 ENTRIES; ALPHABETICAL ORDER; CAPITALIZE ONLY PROPER MAMES; AND SEPARATE KEY WORDS BY SEMICOLONS)} beta backscatter; electrodeposited vs. sputtered standards; energy dispersive $\mathrm{x}$-ray fluorescence; gold coating standards; mass per unit area; SEM gold standards; wavelength dispersive x-ray fluorescence.

\section{AVALABIUTY}




